\title{
INTERNALLY GENERATED GOODWILL ASSESSMENT: CONTEMPORARY TIMES REQUIREMENT OR NOT?
}

Zoran Petrović, Danka Stefanović, Marko Milojević, Nenad Stanić

Faculty of Business in Belgrade, Singidunum University, Belgrade, Serbia

\begin{abstract}
Apstrakt:
Internally generated goodwill (IGG) is an asset that can significantly contribute to the business success of companies. Its value may be very high, although it is not visible directly in the financial statements. IGG value assessment is important not only for companies' owners and managers, but for all external financial statements users as well, and above all potential investors. Considering that accounting standards do not allow presentation of IGG as an asset in balance sheet, reliance on the financial statements in which IGG is not recognized as an asset can mislead users of the financial statements about the company's value and some financial ratios regarding the company's financial position. However, there are methods for IGG approximate value assessment (especially brand) - the value which is sufficiently reliably estimated for the purposes of business decision-making, but not reliable enough for accounting recognition of IGG as an asset in the balance sheet.
\end{abstract}

\section{Ključne reči:}

internally generated goodwill,

brand, assessment,

assessment methods,

financial statements

\section{INTRODUCTION}

In many companies, intangible assets present a significant generator of values. In recent decades, intangibles are in the focus of interest both the economy (companies from different sectors) and science. The rapid development of information technology at the end of the twentieth century has affected all aspects of human life, including the companies' businesses as well. The assets structure of many companies significantly changed. Today, the market is dominated by knowledge-intensive companies, instead of capital intensive which made the profit during past centuries using tangible assets merely.

Some types of intangible assets can be identified and recognized as an asset in the financial statements. Still, that is not always the case with some intangibles. There are assets that are intangible by their nature and significantly contribute to the increasing of company's value and profit as well, but regardless they do not meet the accounting recognition criteria and consequently their value is not presented in the financial statements. One of those assets, which do not meet the accounting recognition criteria, is internally generated goodwill (IGG).

Accounting for IGG is regulated by the International Accounting Standard 38 Intangible Assets (IAS 38). According to IAS 38 (IAS 38:48) IGG cannot be recognized as an asset because it does not represent company's resource that meet all bellow listed criteria:

- it can be identified,

- company controls the asset, and

- the value can be reliably measured (costs of purchase or cost of conversion).

Even though IGG cannot be shown in the financial statements of the company, estimation of its value is important not only for the owners and managers of the company, but also for all external users of financial statements, and especially for all potential investors.

The aim of this paper is to show that in some companies IGG has an extremely high value and represents a significant part of all the companies' assets. Therefore, in this paper we will explain the IGG structure and factors that contribute to its value, as well as the reasons and methods for estimating its value. The purpose of this article is also to draw attention to the existence of methods that can be used to estimate the approximate value of IGG - the value which is sufficiently reliably assessed for the purposes of business decision-making, but not reliable enough for accounting recognition of IGG as an asset in the balance sheet.

\section{IDENTIFICATION OF IGG STRUCTURE}

IGG can be defined as the potential intangible asset of the company (intangibles that did not meet the capitalization criteria) and it is expected that future economic benefits, attributable to the asset, will flow to the company.

According to IAS 38, internally generated intangible assets in the form of generated trademark, mastheads, publishing titles, customer lists and similar items (even though they meet the identifiability criteria) cannot be recognized as intangible assets. The reason for this is the incapability to precisely distinguish the investments made for their creation and the business development costs of the company as a whole. Therefore, these internally generated intangible assets become part of the IGG.

Hence, the most common components of IGG are: brands of the company ${ }^{1}$, brand names (as physical components of brands), publishing titles, investments in human resources capital (knowledge and experience of employees), customers' loyalty, market share of the company, its customer relations, etc. Brands of a company often have a value that is greater than the aggregate value of other intangible assets company has, and even of the total value of all company's fixed assets. The value of IGG is influenced as well by human resources (knowledge and experience of employees), customers' loyalty, market share of the company, its relationship with customers, and others.

1 Brands represent intangible added value that a product, service, company, and others may have. 
IGG represents often the difference between the market value of the company and the book value of its net assets. This difference is a result of many factors affecting the market, and most often it is the result of gained market share, operational management policies and similar (Stefanovic, 2010).

Though IGG cannot be recognized and shown in financial statements, a part of it becomes part of goodwill that is accounted and presented when intangible asset is acquired in a business combination. It is about the part of IGG that does not meet the separability criterion, such as, for example, human resources (knowledge and experience of employees). Hereafter it follows that IGG of a company consists of such intangible assets that are not recognized in the balance sheet as intangible assets but significantly contribute to its business.

\section{REASONS FOR IGG ASSESSMENT}

Although according to IAS 38 recognition of IGG is not allowed due to the inability to reliably assess its value, companies increasingly have a necessity to determine the value of IGG, predominantly due to shareholders' and potential investors' needs. Since accounting standards does not allow IGG recognition as an asset in the balance sheet, reliance on the financial statements in which IGG is not recognized as an asset may mislead the financial statements users regarding the value of the company, as well as the value of some financial position ratios.

IGG assessment is based mostly on a brand value estimation, which is the most important element of IGG. Creating a strong and successful brand requires a lot of funds and other resources, but it also brings companies a higher profit than would be the case if the brand was not built. Investors' brand perceptions have more to do with value realization than value creation. While it is customers' buying behavior that creates revenues and profits for the branded business, investors' brand perceptions will impact how that value is being realized in financial markets (Haxthausen, 2009).

However, there is a question why would companies do value assessment and disclosure of an asset which has no position within the financial statements, neither accounting regulations allow that. One of the business policy objectives of every profitable company is also satisfying the information needs of financial statements external users, whether they are business partners, creditors or potential shareholders. Therefore companies have an interest to estimate the value of IGG and disclose it under the Note.

Investors are very interested in brands of the companies they intend to establish business cooperation with throughout mergers and acquisitions. Despite the fact that IGG is not disclosed in the financial statements, its value represents a performance indicator of a company's businesses. Thus, for example, management of a large pharmaceutical company that have intention to buy another one, smaller and financially weaker, is not interested only in the tangible assets value, but also the value and strength of brand, market share, various recipes, customers' loyalty and others.

The created brand strength has a significant influence on generating the company's future revenues, which is one of the key factors of business in a highly competitive and global business environment. For that reason the IGG assessment is significant for companies. Furthermore, the valuation of IGG may be useful for internal users as well, above all for the management of the companies. Managers often get additional benefits based on profits or increase in share price during the observed period of time. Making (higher) profit of the company has been influenced by IGG also, which implies that an increase in the value of IGG has an impact on increasing profits. One of the bases for determining managers bonuses could be the value of IGG, or increase in the IGG value, that would reflect their contribution to the growth and development of the company's business.
Finally, assessment and determination of the approximate value of IGG, as well as disclosure of information regarding the IGG structure and value, make financial reporting more valid. Financial statements which contain information about the IGG provide a more realistic view of the company's financial position. While this information may be disclosed only within textual report, that does not diminish its importance, quite the opposite, it provides to all users a better insight into the business of a company and its entire assets.

\section{IGG ASSESSMENT METHODS}

Salinas and Ambler (2009) indicate that at least four factors have driven the development of brand valuation methods: measuring marketing performance, justifying share prices, trading brands and tax management. The simplest method for determining the approximate and rough IGG value is calculating the difference between the market value of the company and its book value.

It has been written a lot in the literature on the subject of many different models for brand value assessment, but commonly they are based on one of the three following approaches: cost, market and income approach.

According to the cost approach, brand should be estimated based on historical costs incurred in creating brand or based on estimations how much it may cost to make (create) a similar brand. The weakness of this method is the fact that actual costs often do not represent the total value of a brand at the assessment time because it is often greater than the sum of brand creating costs. Brand valuation is not solely a historical, cost-based measure, but also allows a means to incorporate future results (Otonkue, Edu \& Ezak, 2010).

When there is a possibility to estimate the value of brand, based on transaction in which the same brand was sold at a certain price, then should be used market approach for brand value assessment. This approach is focused on the comparison of the company's brand with the same or similar brand of another company, for which there are available data about the price that was achieved in the market during the sales transactions or acquisition. It is preferable to use data of realized prices that relate to more similar sales of the brand, in order to improve estimate as more accurate and realistic, especially when there is no data about the prices of the same brand, but more similar ones.

When assessing the brand value, multipliers can be used with aim to make some appropriate modifications in order to estimate price reasonable. It is often difficult, sometimes even impossible, to find a suitable transaction that can serve as a reference model for comparison in complete. Therefore, comparison with similar brands is frequently used, with the use of multipliers in order to provide more credible and realistic assessment. The advantage of using market-based approach stems from the fact that the assessment is done by comparing the real historical data, estimating the prices paid for the same or a similar brand. The disadvantage of this method is that there is not always available information about sales prices of the same or similar brands. Brand is a specific type of a company's assets, and its value is influenced by numerous factors including the geographic influences, the market, the time of the transaction, whether the transaction is between related parties or not, etc. As with the cost approach, one of the difficulties for the usage of the market approach is its application for the value assessment of brands that are not uniform and there are not enough available transactions on the market that can be used for comparison.

Income approach is based on the assumption that the future cash flows, attributed to the brand, will determine its value for the owner or potential investor. For that reason it is necessary to determine the value of future revenues, profits or cash flows that are directly related to the brand. There are several differ- 
ent methods used to assess the value of brand within income approach, and most commonly used are royalty relief method, the income split method or incremental cash flow method. Regardless which method of income based approach assessment is used by the company, discounting the projected cash flows is required to make assessment as realistic as possible.

The great significance of the brand for the successful business of the company and the necessity for estimating its value has led to the adoption of the new standard ISO 10668:2010 (Brand valuation - Requirements for monetary brand valuation). Under this standard states that it is important to determine the perspective of perception assessment: whether the valuation of brands is done from the perspective of an ordinary customer (market price), a specific customer (investment cost) or unwilling seller (liquidation value). One must take into consideration also all available financial, behavioral and legal information. This standard states three approaches for assessment too, market, cost and income approach.

\section{EMPIRICAL FINDINGS RELATED TO THE IGG}

In order to illustrate the IGG impact on financial reporting, we will use data from financial statements of two local companies, for the year 2013: Apatinska Brewery from Apatin and the brewery Carlsberg from Celarevo. Both companies have very strong and valuable brands. The value of fixed assets (property, plant and equipment) dated Decembar 31, 2013 of the Apatinska Brewery amounted RSD 6.1 billion, while brewery Carlsberg amounted RSD 5.1 billion. Accordingly, the difference between the value of fixed assets of these companies is not high (18.6\%) and it represents the higher capacity of Apatinska Brewery.

Therefore, it seems logical that other assets positions in the balance sheet are in the same or a similar proportion, higher in Apatinska Brewery. However, comparing the total assets sums of both breweries shows a surprising fact: the total assets of Apatinska Brewery amount RSD 18.6 billion, while brewery Carlsberg assets amount RSD 8.3 billion. Accordingly the Apatinska Brewery assets are more than twice as high. If it would be judged about the company's size based only on the total assets sum, that would lead to the wrong conclusion that the Apatinska Brewery has more than RSD 10 billion more valuable assets comparing to Carlsberg brewery from Celarevo, respectively more than twice as high. Nonetheless, with additional insight into the structure of assets and reading the Notes it can be seen that Apatinska Brewery has recognized brands worth RSD 9.2 billion, unlike Carlsberg brewery that has no recognized brands, even though it has very valuable brands.

Consequently, there are following question arising:

1) Is the recognition of brands and trademarks in the balance sheet not allowed by IAS 38 ?

- This standard prohibits capitalization of internally generated brands and trademarks, but allows the recognition of externally acquired brands and trademarks as assets. This means that Apatinska Brewery had acquired their brands and trademarks by buying or investing;

2) What is the value of Carlsberg brands, the brewery from Celarevo?

- Applying some of the aforementioned methods for estimating brands could be sufficiently reliable to determine the value of brands, which this company disposes. However, their true value could be checked only on the market - within the buying and selling transaction.

Taking into consideration the above stated, financial analysis ratios for these two companies, which deals with total or fixed assets, become incomparable, or may provide an unrealistic image of the company and its financial position. It can be said that these ratios should be considered very carefully for all companies that have their valuable brands and trademarks unrecognized.

Analyzing the financial statements of our best-known companies in the food industry (Bambi, Pionir, Soko Stark, etc.) it can be concluded that these companies do not have presented value of brands and trademarks in their financial statements, though these are, in our environment, worth assets - they mostly created their brands and trademarks themselves. Therefore, all of those who make conclusions based on their financial statements should have in mind that limit.

\section{CONCLUSION}

Brands and trademarks are the assets of the company that may have a very high individual values. In most companies these are internally generated assets which are consequently unrecognized in the balance sheet. The need for estimation the value of these assets arises from the intention to complete a purchase or sale of these assets, to assess the value of the company (with the aim of making transactions with its capital), as well as to evaluate the financial position and performance of the company. Financial analysts, who make conclusions regarding the financial position and performance of companies based on financial statements, must be aware of how failures to present IGG in assets affects financial ratios. Further development of economy and society goes towards increasing share of IGG in companies' assets. Therefore, it is reasonable to expect that economic theory and practice focus on improving methods for the assessment of brands, trademarks, and other components of the IGG.

\section{REFERENCES}

[1] A. D. O. Otonkue, B. E. Edu \& E. Ezak, "Accounting for Brands: Contemporary Issues and Alternative Options", IUP Journal of Brand Management, March 2010, Vol. 7, Issue $1 / 2$, pp. 105-115.

[2] D. Stefanović, "Nematerijalna ulaganja u savremenim organizacijama sveta rada", Univerzitet Singidunum, Beograd, 2010, [available on site http://www.singipedia. singidunum.ac.rs/content/1836-Nematerijalna-ulaganjau-savremenim-organizacijama-sveta-rada]

[3] G. Salinas \& T. Ambler, "A taxonomy of brand valuation practice: Methodologies and purposes", Journal of Brand Management, Vol. 17, Issue 1, September 2009, pp. 39-61.

[4] http://www.apr.gov.rs/ (access: 28/09/2014)

[5] Međunarodni računovodstveni standard 38 (access: 01.10.2014), [available on site http://mfin.gov.rs/UserFiles/File/MRS/Medunarodni\%20racunovodstveni\%20 standard\%2038\%20-\%20Nematerijalna\%20imovina.pdf]

[6] Međunarodni standard finansijskog izveštavanja 3 (access: 01/10/2014), [available on site http://www.privreda.gov. rs/UserFiles/File/MRS/Medunarodni\%20standard\%20 finansijskog\%20izvestavanja $\% 203 \% 20-\% 20$ Poslovne $\% 20$ kombinacije.pdf]

[7] O. Haxthausen, "Valuing brands and brand investments: Key learnings and future expectations", Journal of Brand Management, September 2009, Vol. 17, Issue 1, pp. 18-25.

[8] Z. Petrović, Finansijsko izveštavanje, Univerzitet Singidunum, Beograd, 2011, [available on site http://www. singipedia.singidunum.ac.rs/content/2193-Finansijskoizve\%C5\%A1tavanje] 
PROCENA INTERNO STVORENOG GOODWILL-A: POTREBA SAVREMENOG DOBA ILI NE?

Zoran Petrović ${ }^{1}$, Danka Stefanović 2 , Marko Milojevićc ${ }^{3}$ Nenad Stanić ${ }^{4}$

${ }^{1}$ Poslovni fakultet u Beogradu, Univerzitet Singidunum Danijelova 32, Beograd, Srbija, zpetrovic@singidunum.ac.rs

${ }^{2}$ Poslovni fakultet u Beogradu, Univerzitet Singidunum Danijelova 32, Beograd, Srbija, dstefanovic@singidunum.ac.rs

${ }^{3}$ Poslovni fakultet u Beogradu, Univerzitet Singidunum Danijelova 32, Beograd, Srbija,, mmilojevic@singidunum.ac.rs

${ }^{4}$ Poslovni fakultet u Beogradu, Univerzitet Singidunum Danijelova 32, Beograd, Srbija, nstanic@singidunum.ac.rs

\section{Apstrakt:}

Interno stvoreni goodwill (ISG) je sredstvo koje značajno može da doprinose uspešnosti poslovanja kompanija. Njegova vrednost može biti veoma velika, iako nije direktno vidljiva u finansijskim izveštajima. Utvrđivanje njegove vrednosti je od značaja ne samo za vlasničku i rukovodeću strukturu kompanija, već i za sve eksterne korisnike finansijskih izveštaja, a pre svega potencijalne investitore. S obzirom da računovodstvena regulativa ne dozvoljava iskazivanje ISG kao sredstva u bilansu stanja, oslanjanje na finansijske izveštaje u kojima ISG nije priznat kao sredstvo može dovesti korisnike finansijskih izveštaja u zabludu o vrednosti kompanije i visini pojedinih pokazatelja finansijskog položaja kompanije. Postoje metode kojima se može utvrditi približna vrednost ISG (pre svega brenda) - vrednost koja je za svrhe poslovnog odlučivanja dovoljno pouzdano utvrđena, ali ne i dovoljno pouzdana za računovodstveno priznavanje ISG kao sredstva u bilansu stanja.

\section{Ključne reči:}

interno stvoreni goodwill, brend, procena,

metode procene,

finansijski izveštaji. 